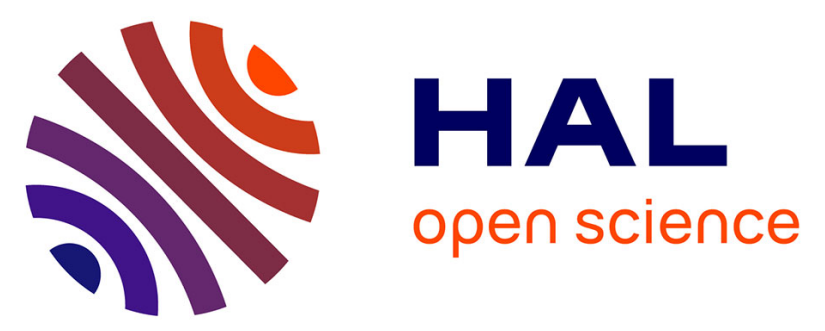

\title{
Evaluation of a new method for the measurement of corneal thickness in eye bank posterior corneal lenticules using Anterior Segment Optical Coherence Tomography
}

\author{
Domenico Amato, Marco Lombardo, Francesco Oddone, Mario Nubile, \\ Rossella A.M. Colabelli-Gisoldi, Carlo Maria Villani, Sonia Yoo, Jean-Marie \\ Parel, Augusto Pocobelli
}

\section{To cite this version:}

Domenico Amato, Marco Lombardo, Francesco Oddone, Mario Nubile, Rossella A.M. ColabelliGisoldi, et al.. Evaluation of a new method for the measurement of corneal thickness in eye bank posterior corneal lenticules using Anterior Segment Optical Coherence Tomography. British Journal of Ophthalmology, 2010, 95 (4), pp.580. 10.1136/bjo.2010.190595 . hal-00596283

\section{HAL Id: hal-00596283 https://hal.science/hal-00596283}

Submitted on 27 May 2011

HAL is a multi-disciplinary open access archive for the deposit and dissemination of scientific research documents, whether they are published or not. The documents may come from teaching and research institutions in France or abroad, or from public or private research centers.
L'archive ouverte pluridisciplinaire HAL, est destinée au dépôt et à la diffusion de documents scientifiques de niveau recherche, publiés ou non, émanant des établissements d'enseignement et de recherche français ou étrangers, des laboratoires publics ou privés. 


\section{Evaluation of a new method for the measurement of corneal thickness in}

2 eye bank posterior corneal lenticules using Anterior Segment Optical

\section{Coherence Tomography}

4

5 Domenico Amato $^{1 *}$, Marco Lombardo ${ }^{1}$, Francesco Oddone ${ }^{1}$, Mario Nubile ${ }^{2}$, Rossella AM

6 Colabelli Gisoldi $^{3}$, Carlo M Villani ${ }^{3}$, Sonia Yoo ${ }^{4}$, Jean-Marie Parel $^{4}$, Augusto Pocobelli ${ }^{3}$

7

8

9

${ }^{1}$ IRCCS Fondazione G. B. Bietti, Rome, Italy.

${ }^{2}$ Department of Medicine and Ageing Science, Ophthalmology Clinic, University of ChietiPescara, Italy.

${ }^{3}$ S. Giovanni - Addolorata - Britannico Hospital, Rome, Italy.

${ }^{4}$ Bascom Palmer Eye Institute, University of Miami Miller School of Medicine, Miami, Florida, USA

Supported in part by the Eye Bank of Rome, S.Giovanni - Addolorata - Britannico Hospital, Rome, Italy and the Florida Lions Eye Bank, Miami, FL, USA

* Corresponding Author:

Domenico Amato,

Via Merulana, 143

00184 Rome, Italy

Fax: +3906 77055844

Telephone: +390677055952

E-mail: damato@hsangiovanni.roma.it

Keywords: DSAEK, eye bank, precut tissue, AS-OCT

Word Count: 1.540 


\section{Abstract}

34 Background/aims: To preliminary evaluate the repeatability of central corneal thickness

35 (CCT) measurements performed with Anterior Segment Optical Coherence Tomography (AS-

36 OCT) on eye bank posterior corneal lenticules.

37 Methods: Six donor lenticules were created with a $350 \mu \mathrm{m}$ head microkeratome (Moria, Antony, France). All donor tissues were stored at $4{ }^{\circ} \mathrm{C}$ in Eusol-C solution (Alchimia S.r.l, Ponte S. Nicolò, Italy), without the anterior cornea lamella. The CCT of each lenticule, maintained in the glass vial, was measured using a commercial AS-OCT instrument (Visante, Carl Zeiss Meditec, Dublin, CA, USA) and a special designed adaptor immediately and 4-, 42 24- and 48-hours after dissection. Immediately after AS-OCT, CCT values were measured with the ultrasound (US) pachymetry method used at the Eye Bank.

Results: The mean donor cornea central thickness was $647 \pm 36 \mu \mathrm{m}$ and $660 \pm 38 \mu \mathrm{m}$ $(\mathrm{P}=0.001)$ as measured by AS-OCT and US respectively; immediately after dissection, CCT values of posterior lenticules were $235 \pm 43 \mu \mathrm{m}$ and $248 \pm 44 \mu \mathrm{m}$ respectively $(\mathrm{P}=0.001)$. No statistically significant changes in CCT values of donor lenticules were assessed over the 48 hours period with both methods. There was a high level of agreement, evidenced by BlandAltman analysis, between the two methods of pachymetry.

Conclusion: AS-OCT, with the corneal tissue in the vial, revealed to be a repeatable and reliable method for measuring posterior donor lenticule central thickness. Lenticule CCT values measured with the investigational AS-OCT method were on average $10 \mu \mathrm{m}$ thinner than those measured with the established US method. 


\section{Introduction}

58 Descemet's stripping automated endothelial keratoplasty (DSAEK) $)^{1,2}$ is a surgical technique

59 for the treatment of corneal endothelial diseases. The preparation of DSAEK donor tissue

60 was originally done in the operating room by the surgeon ${ }^{3,4}$ but currently an increasing

61 number of surgeons prefers to obtain donor tissue directly from the eye bank just before

62 tissue shipment ${ }^{5,6}$. Precut donor tissue for DSAEK offers the advantage of saving surgery

63 time with precise information regarding central thickness, providing at the same time visual

64 and refractive outcomes and rate of postoperative complications comparable to surgeon-

65 dissected donor tissue $7,8,9,10,11$.

66 Contact ultrasound (US) pachymetry is in general the preferred method for measuring the

67 corneal thickness in eye bank worldwide ${ }^{5,7}$. Anterior Segment Optical Coherence

68 Tomography (AS-OCT) has been also recently used for characterizing eye-bank donor

69 tissues $^{12}$. AS-OCT is a non-contact method that can give central and peripheral thickness

70 measurements of the entire cornea and it is widely used in the clinical environment for the

71 examination of DSAEK donor tissue during follow-up of patients. On the other hand, the

72 knowledge of either central or peripheral thickness values before surgery may be valuable

73 for DSAEK surgeons, since it has been widely demonstrated how either the central thickness

74 or a non-uniform thickness profile of the donor tissue may influence the definite refractive

75 outcome after surgery ${ }^{13,14,15,16}$. The purpose of this study was to preliminary evaluate a new

76 method for measuring the central thickness of posterior corneal lenticules using a

77 commercial AS-OCT instrument. A custom adaptor was used in order to maintain the tissue

78 in the glass vial, thus avoiding tissue manipulation during measurements. 


\section{Methods}

82 Six donor corneas obtained from the eye bank of Rome (Italy) were used for the study. All

83 corneas were used within 4 days post-mortem and were stored at $4^{\circ} \mathrm{C}$ in corneal storage medium Eusol-C (Alchimia S.r.l, Ponte S. Nicolò, Italy). The donors had a negative ophthalmic history but positive serology, which made the tissue unsuitable for transplantation.

All tissues were prepared by an expert eye bank operator (DA) using the standardized method for obtaining DSAEK precut tissues at the eye bank of Rome ${ }^{17}$. Each corneal lenticule was prepared from the donor cornea by using a $350 \mu \mathrm{m}$ head microkeratome (Moria One, Moria S.A., Antony, France) and an artificial anterior chamber (AAC, Moria S.A., Antony, France) cushioned with Eusol-C. Each lenticule was created by a full pass of the microkeratome blade which resulted in a posterior lamellar donor and a free cap. The free anterior cap was then eliminated and the posterior lamellar tissue was stored over a period of 48 hours at $4^{\circ} \mathrm{C}$ in Eusol- $\mathrm{C}$ between measurements.

Donor corneal central thickness (CCT) before dissection and lenticule CCT immediately and after 4-, 24- and 48-hours post-cut were first measured by AS-OCT (Visante, Carl Zeiss Meditec, Dublin, CA, US) and then by US pachymetry using a $20 \mathrm{MHz}$ probe (Hiscan, Optikon 2000 S.p.A., Rome, Italy), capable of measuring thickness values lower than $100 \mu \mathrm{m}$ and calibrated by the manufacturer. Measurements were performed 5 times by the same operator to assess repeatability of both methods. optical path of the AS-OCT instrument allowing to carry out measurements through the 
106 Florida, USA)_does not require modification of the AS-OCT instrument and can be plugged

107 in/removed without compromising tissue sterility.

108 In the AS-OCT image, the corneal apex was identified from the peak of the reflectivity 109 profile on the horizontal axis and the automated flap tool of the instrument was then used for

110 thickness measurement. US pachymetry was obtained in a perpendicular direction from the

111 corneal surface to the central cornea by direct contact of the probe with the corneal tissue

112 mounted on the AAC cushioned with Eusol-C and pressurized to approximately $40 \mathrm{mmHg}$,

113 as measured with hand-held applanation tonometry (Tono-pen, Mentor Ophthalmics,

114 Norwell, MA, US). The tip of the probe was wetted using Eusol-C.

115 Statistical analysis

116 Repeatability was determined with the coefficient of variation $(\mathrm{CV})$ value, expressed in \%,

117 that was calculated from the intrasession standard deviations for the five independent

118 consecutive measurements. Bland-Altman plots were used to assess the degree of agreement

119 between AS-OCT and US pachymetry and their 95\% confidence interval. Differences in

120 measurements between AS-OCT and US were evaluated by paired $t$-test. A $P$ value of 0.05

121 or less was considered statistically significant. Statistical data analysis was carried out using

122 SPSS for Windows (version 10.0, SPSS Inc.).

\section{Results}

126 The mean central corneal thickness before dissection was $647 \pm 35 \mu \mathrm{m}$ and $660 \pm 38 \mu \mathrm{m}$

$127(P=0.001)$, as measured by AS-OCT and US respectively. Immediately after dissection,

128 posterior lenticule CCT values were $235 \pm 43 \mu \mathrm{m}$ and $248 \pm 44 \mu \mathrm{m}$, as measured by AS-

129 OCT and US respectively $(P<0.001)$. No statistically significant changes in lenticule CCT 


\begin{tabular}{|c|c|c|c|c|c|c|}
\hline \multicolumn{7}{|c|}{$\begin{array}{c}\text { Table } 1 \\
\text { Central corneal thickness values and coefficient of variation }(\mathrm{CV}, \%) \\
\text { calculated with the investigational AS-OCT and US methods of pachymetry } \\
\text { during the time course }\end{array}$} \\
\hline & Variable & Pre-cut* & $\begin{array}{c}\text { Post-cut } \\
(\mathrm{p}-\mathrm{c})^{*}\end{array}$ & $\begin{array}{c}4 \text { hours } \\
\text { p-c* }\end{array}$ & $\begin{array}{c}24 \text { hours } \\
\text { p-c* }\end{array}$ & $\begin{array}{c}48 \text { hours } \\
\text { p-c* }\end{array}$ \\
\hline \multirow{4}{*}{$\begin{array}{l}\text { AS- } \\
\text { OCT }\end{array}$} & $\operatorname{Mean}( \pm \mathrm{SD}, \mu \mathrm{m})$ & $647 \pm 35$ & $235 \pm 43$ & $224 \pm 37$ & $239 \pm 42$ & $233 \pm 39$ \\
\hline & $\operatorname{Min}(\mu \mathrm{m})$ & 594 & 173 & 181 & 187 & 185 \\
\hline & $\operatorname{Max}(\mu \mathrm{m})$ & 690 & 280 & 271 & 281 & 277 \\
\hline & $\mathrm{CV}(\%)$ & $5 \%$ & $18 \%$ & $16 \%$ & $18 \%$ & $17 \%$ \\
\hline \multirow{4}{*}{ US } & Mean $( \pm \mathrm{SD}, \mu \mathrm{m})$ & $660 \pm 38$ & $248 \pm 44$ & $238 \pm 42$ & $247 \pm 41$ & $240 \pm 40$ \\
\hline & $\operatorname{Min}(\mu \mathrm{m})$ & 605 & 185 & 188 & 195 & 189 \\
\hline & $\operatorname{Max}(\mu \mathrm{m})$ & 705 & 298 & 283 & 289 & 282 \\
\hline & $\mathrm{CV}(\%)$ & $6 \%$ & $18 \%$ & $17 \%$ & $17 \%$ & $17 \%$ \\
\hline
\end{tabular}

133

values (1-way ANOVA, $P>0.05$ ) were assessed during the post-cut time course, as measured by both devices (table 1$)$.

Central corneal thickness values and coefficient of variation $(\mathrm{CV}, \%)$ during the time course 
after cut. Full details with 95\% LOA are given in figure 2. An example of the AS-OCT imaging of a corneal tissue during the time course of examinations is shown in figure 3.

\section{Discussion}

AS-OCT is a valuable imaging tool for providing information on donor posterior lamella apposition after DSAEK and further in the management of surgical complications after the procedure, such as dislocation, primary graft failure, and anterior chamber crowding with consequent chamber angle encroachment and pupillary block ${ }^{19}$. On the other hand, AS-OCT may provide useful information prior to surgery, with detailed description of central thickness and profile of donor tissue. Recently, a custom built AS-OCT has been demonstrated to be a potential instrument for the preoperative eye bank routine analysis of donor lamellar tissues for transplantation ${ }^{12}$. In this work we aimed at preliminary estimating the repeatability of a new method for measuring donor corneal thickness of eye bankprepared tissues for DSAEK using a commercial AS-OCT device. A special-designed adaptor was used to maintain the cornea in the glass vial during AS-OCT measurements. CCT values obtained with the investigational AS-OCT method were compared to those performed with the established US method of pachymetry at our eye bank. There was a high level of agreement between methods with mean differences of approximately $10 \mu \mathrm{m}$ before and after dissection. A high repeatability of the investigational AS-OCT method of central pachymetry, comparable to US pachymetry, was calculated and further confirmed previous findings ${ }^{20,21}$. In our study, mean AS-OCT central pachymetry revealed lower values, ranging from 7 to $14 \mu \mathrm{m}$, than US pachymetry, both before and after dissection. The results from the present work are in accordance with several clinical studies that have been conducted with the aim to compare corneal thickness measurements obtained with different devices, 
166 including US and AS-OCT ${ }^{21,22,23,24,25,26,27}$. In general, all the authors have reported a

167 reproducible systematic difference between CCT measurements taken with US and OCT,

168 with the latter method providing an average underestimation of approximately $15-30 \mu \mathrm{m}$ of

169 central pachymetry readings.

170 Possible bias in the measurement of CCT values between AS-OCT and US methods of

171 pachymetry could be introduced by the fact that, during AS-OCT measurements, the corneal

172 tissue was completely immersed in liquid and it was not pressurized into the AAC as done

173 during US measurements. A potential source of error in the conversion from OCT distance to

174 geometric thickness is therefore the assumption of a constant corneal refractive index, as in

175 general discussed for the OCT technique ${ }^{28,29}$. Although changes of the refractive index were

176 considered unlikely, intra-individual and local variations of the refractive index, due to

177 increasing hydration and thickening of corneal tissue, could influence the propagation of light

178 through different corneal layers ${ }^{30,31}$ : a constant corneal thickness, however, has been

179 measured during the time course of examinations in all specimens. On the other hand, one

180 should bear in mind how the sound velocity in corneal tissue has been a subject of long debate

181 and the speed of sound is likely to vary between different layers of the cornea ${ }^{32}$. Moreover, it

182 is unlikely to take thickness measurements precisely at the corneal apex with US pachymetry.

183 Although the limited number of cases, the investigational AS-OCT system provided a non-

184 contact and repeatable method in the evaluation of corneal thickness of posterior donor cornea

185 lenticules. The measurement of corneal thickness directly inside the vial can reduce the

186 mounting time of the cornea on the artificial anterior chamber, thereby minimizing the stress

187 placed upon the endothelium and the risks of contamination; in addition, the method can

188 quantify the tissue swelling rate during prolonged storage at the eye bank and has the

189 potential to provide information about regional variations in the donor lenticule profile that

190 could be used to correlate with postoperative DSAEK outcomes ${ }^{16}$. Notwithstanding these 
191

192

193

194

195

196

197

advantages, the cost of an AS-OCT instrument is clearly a hindering factor when compared to that of an US pachymeter and could limit a widespread use by eye banks.

\section{Acknowledgments}

The authors are thankful to Cornelius Rowaan BSEM, William Lee and Izuru Nos BSEE, from the Ophthalmic Biophysics Center of the Bascom Palmer Eye Institute, for fabricating the AS-OCT adaptor used in this study. Funds for construction were generously provided by the Florida Lions Eye Bank in Miami Florida. .

The authors finally are thankful to Cesare Amici and Roberto Donati, from the eye bank of Rome, for their help in processing donor corneas used in this study.

The authors are thankful to Al.chi.mi.a. Srl (Padova, Italy) for their support during the experiments.

\section{Competing Interests}

The authors have no financial or commercial interest in the materials described herein

\section{Copyright licence statement}

The Corresponding Author has the right to grant on behalf of all authors and does grant on behalf of all authors, an exclusive licence on a worldwide basis to the BMJ Group and coowners or contracting owning societies (where published by the BMJ Group on their behalf), and its Licensees to permit this article (if accepted) to be published in British Journal of 
213 Ophthalmology and any other BMJ Group products and to exploit all subsidiary rights, as set

214 out in our licence.

215 References

216 1) Gorovoy MS. Descemet-stripping automated endothelial keratoplasty. Cornea 2006; 25 :

217 886-889.

218 2) Terry MA. Endothelial keratoplasty: history, current state, and future directions. Cornea. $219 \quad 2006 ; 25: 873-878$.

220 3) Price MO, Price FW. Descemet's stripping with endothelial keratoplasty. Comparative 221 outcomes with microkeratome-dissected and manually dissected donor tissue.

222 Ophthalmology 2006; 113: 1936-1942.

223 4) Koenig SB, Dupps WJ, Covert DJ, Meisler DM. Visual acuity, refractive error, and 224 endothelial cell density six months after Descemet stripping and automated endothelial 225 keratoplasty (DSAEK). Cornea 2007; 26: 670-674.

226 5) Rose L, Briceño CA, Stark WJ, Gloria DG, Jun AS. Assessment of eye-bank-prepared 227 posterior lamellar corneal tissue for endothelial keratoplasty. Ophthalmology 2008; 115 : $228 \quad 279-286$.

6) Ide T, Yoo SH, Kymionis GD, Goldman JM, Perez VL, O’Brien TP. Descemet-stripping automated endothelial keratoplasty: effect of anterior lamellar corneal tissue-on/off storage condition on Descemet-stripping automated endothelial keratoplasty donor tissue. Cornea 2008; 27: 754-757. 
236 8) Chen ES, Terry MA, Shamie N, Phillips PM, Hoar KL, Friend DJ. Precut tissue in

237 Descemet's stripping automated endothelial keratoplasty. Donor characteristics and early

238 postoperative complications. Ophthalmology 2008; 115: 497-502.

239 9) Price MO, Baig KM, Brubaker JW, Price FW Jr. Randomized, prospective comparison of

240 precut vs surgeon-dissected grafts for Descemet stripping automated endothelial keratoplasty.

241 Am J Ophthalmol 2008; 146: 36-41.

242 10) Terry MA, Shamie N, Chen ES, Phillips PM, Hoar KL, Friend DJ. Precut tissue for

243 Descemet's stripping endothelial keratoplasty. Vision, astigmatism and endothelial survival.

244 Ophthalmology 2009; 116: 248-256.

245 11) Terry MA. Endothelial keratoplasty: a comparison of complication rates and endothelial

246 survival between precut tissue and surgeon cut tissue by a single DSAEK surgeon. Trans Am

247 Ophthalmol Soc 2009; 107: 184-191.

248 12) Brown JS, Wang D, Li X, Baluyot F, Iliakis B, Lindquist TD, Shirakawa R, Shen TT, Li

249 X. In situ ultrahigh-resolution optical coherence tomography characterization of eye bank

250 corneal tissue processed for lamellar keratoplasty. Cornea 2008; 27: 802-810.

251 13) Dupps WJ, Qian Y, Meisler DM. Multivariate model of refractive shift in Descemet-

252 stripping automated endothelial keratoplasty. J Cataract Refract Surg 2008; 34: 578-584.

253 14) Jun B, Kuo AN, Afshari NA, Carlson AN, Kim T. Refractive change after Descemet

254 stripping automated endothelial keratoplasty surgery and its correlation with graft thickness

255 and diameter. Cornea 2009; 28: 19-23.

256 15) Holz HA, Meyer JJ, Espandar L, Tabin GC, Mifflin MD, Moshirfar M. Corneal profile

257 analysis after Descemet stripping endothelial keratoplasty and its relationship to

258 postoperative hyperopic shift. J Cataract Refract Surg 2008; 34: 211-214. 
16) Lombardo M, Terry MA, Lombardo G, Boozer DD, Serrao S, Ducoli P. Analysis of posterior donor corneal parameters one-year after Descemet Stripping Automated Endothelial Keratoplasty (DSAEK) triple procedure. Graefe's Arch Ophthalmol 2010; 248: $421-427$

17) Amato D, Oddone F, Nubile M, Colabelli Gisoldi RA, Villani CM, Pocobelli A. Precut donor tissue for Descemet Stripping Automated Keratoplasty: anterior hinged lamella On versus Off. Br J Ophthalmol 2009; 94: 519-522.

18) Yoo S, De Freitas C, Lee B, Nose I, Pena J, Triglia C, Uhlhorn S, Dubovy S, Culbertson W, Parel J-M. Anterior Chamber OCT adaptor to assess intact and precut Eye Bank Corneal buttons for PK and DSEAK. Invest Ophthalmol Vis Sci 2009; 50: E-Abstract 6211

19) Lim LS, Aung HT, Aung T, Tan DTH. Corneal imaging with anterior segment optical coherence tomography for lamellar keratoplasty procedures. Am J Ophthalmol 2008; 145: $81-90$.

20) Muscat S, McKay N, Parks S et al. Repeatability and reproducibility of corneal thickness measurements by optical coherence tomography. Invest Ophthalmol Vis Sci 2002; 43: 17911795.

21) Kim HY, Budenz DL, Lee PS, Feuer WJ, Barton K. Comparison of central corneal thickness using anterior segment optical coherence tomography vs ultrasound pachymetry. Am J Ophthalmol 2008; 145: 228-232.

22) Zhao PS, Wong TY, Wong WL, Saw SM, Aung T. Comparison of central corneal thickness measurements by Visante anterior segment optical coherence tomography with ultrasound. Am J Ophthalmol. 2007; 143: 1047-1049.

23) Schneider M, Borgulya G, Seres A, Nagy Z, Nemeth J. Central corneal thickness measurements with optical coherence tomography and ultrasound pachymetry in healthy 
subjects and in patients after photorefractive keratectomy. Eur J Ophthalmol 2009; 19: 180187.

24) Li EY, Mohamed S, Leung CK, Rao SK, Cheng AC, Cheung CY, Lam DS. Agreement among 3 methods to measure corneal thickness: ultrasound pachymetry, Orbscan II, and Visante anterior segment optical coherence tomography. Ophthalmology 2007; 114: 18421847.

25) Wong AC, Wong CC, Yuen NS, Hui SP. Correlational study of central corneal thickness measurements on Hong Kong Chinese using optical coherence tomography, Orbscan and ultrasound pachymetry. Eye 2002; 16: 715-721.

26) Ho T, Cheng AC, Rao SK, Lau S, Leung CK, Lam DS. Central corneal thickness measurements Orbscan II, Visante, ultrasound, and Pentacam after laser in situ keratomileusis for myopia. J Cataract Refract Surg 2007; 33: 1177-1182.

27) Buehl W, Stojanac D, Sacu S, Drexler W, Findl O. Comparison of three methods of measuring corneal thickness and anterior chamber depth. Am J Ophthalmol 2006; 141: 7-12. 28) Wirbelauer C, Scholz C, Hoerauf H, Pham DT, Laqua H, Birngruber R. Noncontact corneal pachymetry with slit lamp-adapted optical coherence tomography. Am J Ophthalmol 2002; 133: 444-450.

29) Hitzenberger CK, Baumgartner A, Drexler W, Fercher AF. Interferometric measurement of corneal thickness with micrometer precision. Am J Ophthalmol 1994; 118: 468-476. 30) Drexler W, Hitzenberger CK, Baumgartner A, Findl O, Sattmann H, Fercher AF. Investigation of dispersion effects in ocular media by multiple wavelength partial coherence interferometry. Exp Eye Res 1998; 66: 25-33.

31) Olsen T, Nielsen CB, Ehlers N. On the optical measurement of corneal thickness. I. Optical principle and sources of error. Acta Ophthalmol 1980; 58: 760-766. 
307

308

309

310

311

312

\section{$313 \quad$ Figure Legends}

32) Silverman RJ, Patel MS, Gal O, Sarup A, Deobhakta A, Dababneh H, Reinstein DZ,

Feleppa EJ, Coleman DJ. Effect of Corneal Hydration on Ultrasound Velocity and Backscatter. Ultrasound Med Biol 2009; 35: 839-846.

Figure 1. The eye bank tissue adaptor does not require modification of the AS-OCT instrument and can be easily plugged in/removed without compromising sterility of the donor corneal tissue. A) The device consists of a holder accepting standard glass vials or plastic viewing chambers and a fixation mechanism fitting the AS-OCT. B) front and C): top views of the device.

Figure 2. Bland-Altman plots analyzing the agreement between AS-OCT and US thickness measurements. Average and difference CCT values between methods of pachymetry are plotted in the $x$ - and $y$-axes respectively. A) measurements before the microkeratome dissection; B) measurements immediately after dissection; C) at 4 hours post-cut; D) at 24 hours and E) at 48 hours post-cut. All measurements were within 95\% LOA.

Figure 3. AS-OCT images of a corneal sample obtained during tissue storage. The corneal central thickness was $670 \mu \mathrm{m}$ before dissection (A). The posterior lenticule central corneal thickness was $240 \mu \mathrm{m}$ immediately after dissection (B); 250 microns at 4 hours (C); $230 \mu \mathrm{m}$ at 24 hours (D) and $220 \mu \mathrm{m}$ at 48 hours post-cut (E). Thickness measurement was done by using the automated flap tool of the instrument. 


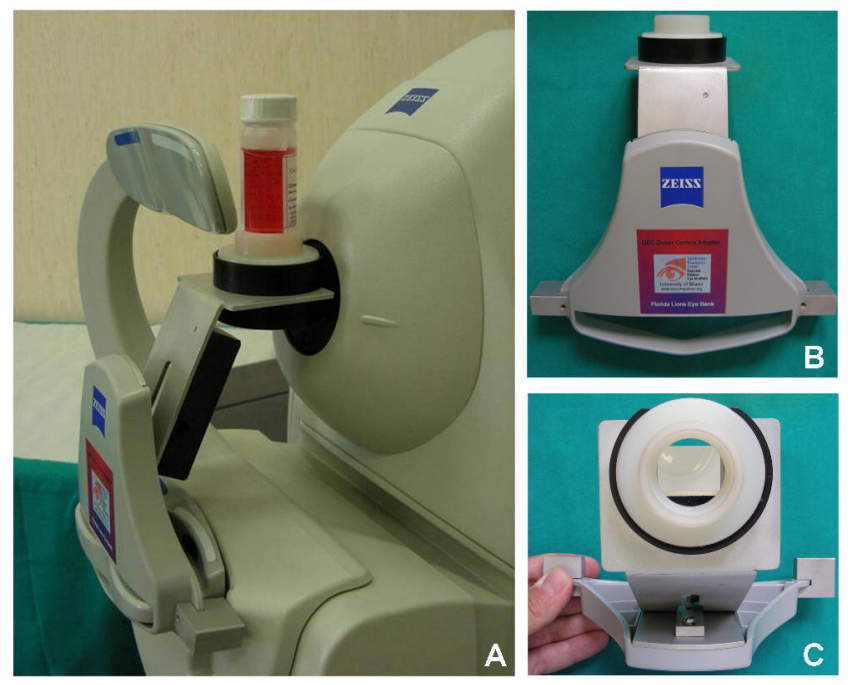



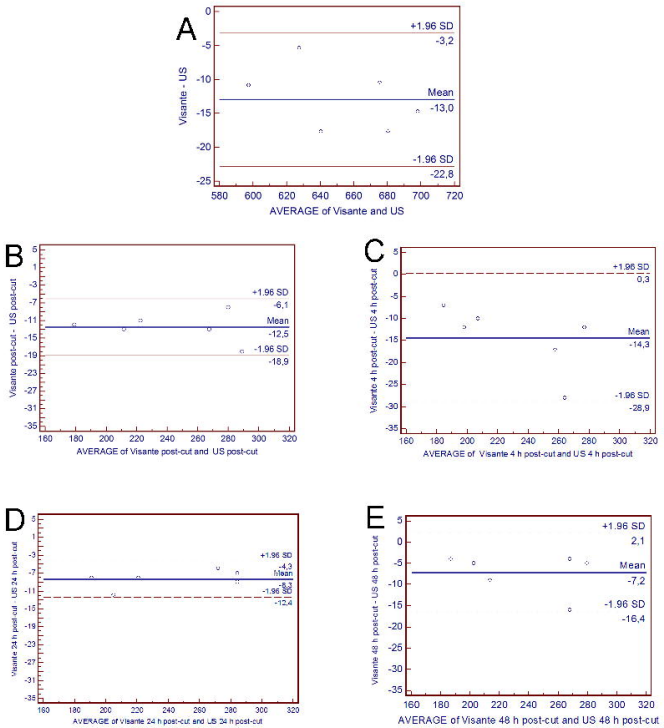

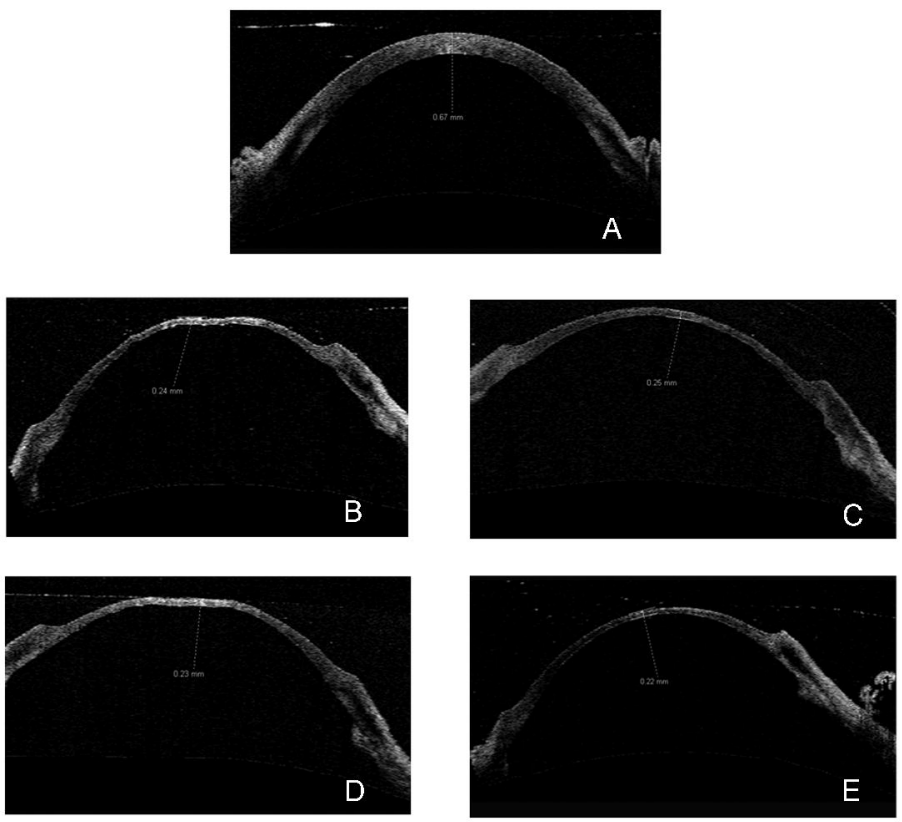